\title{
Weekly water quality monitoring data for the River Thames (UK) and its major tributaries (2009-2013): the Thames Initiative research platform
}

\author{
Michael J. Bowes, Linda K. Armstrong, Sarah A. Harman, Heather D. Wickham, David J. E. Nicholls, \\ Peter M. Scarlett, Colin Roberts, Helen P. Jarvie, Gareth H. Old, Emma Gozzard, \\ Nuria Bachiller-Jareno, and Daniel S. Read \\ Centre for Ecology and Hydrology, Benson Lane, Crowmarsh Gifford, Wallingford, \\ Oxfordshire, OX10 8BB, UK \\ Correspondence: Michael J. Bowes (mibo@ceh.ac.uk)
}

Received: 15 December 2017 - Discussion started: 2 January 2018

Revised: 24 July 2018 - Accepted: 26 July 2018 - Published: 11 September 2018

\begin{abstract}
The River Thames and 15 of its major tributaries have been monitored at weekly intervals since March 2009. Monitored determinands include major nutrient fractions, anions, cations, metals, $\mathrm{pH}$, alkalinity, and chlorophyll $a$ and are linked to mean daily river flows at each site. This catchment-wide biogeochemical monitoring platform captures changes in the water quality of the Thames basin during a period of rapid change, related to increasing pressures (due to a rapidly growing human population, increasing water demand and climate change) and improvements in sewage treatment processes and agricultural practices. The platform provides the research community with a valuable data and modelling resource for furthering our understanding of pollution sources and dynamics, as well as interactions between water quality and aquatic ecology. Combining Thames Initiative data with previous (non-continuous) monitoring data sets from many common study sites, dating back to 1997 , has shown that there have been major reductions in phosphorus concentrations at most sites, occurring at low river flow, and these are principally due to reduced loadings from sewage treatment works (STWs). This ongoing monitoring programme will provide the vital underpinning environmental data required to best manage this vital drinking water resource, which is key for the sustainability of the city of London and the wider UK economy. The Thames Initiative data set is freely available from the Centre for Ecology and Hydrology's (CEH) Environmental Information Data Centre at https://doi.org/10.5285/e4c300b1-8bc3-4df2-b23a-e72e67eef2fd.
\end{abstract}

\section{Introduction}

The River Thames and its tributaries play a vital role in sustaining the ca. 13 million inhabitants of the Thames basin, including the UK capital, London. The river system supplies most of their drinking water and also provides a means of exporting human and industrial wastes, by receiving and transporting wastewater treatment effluents. The rivers also provide important recreational services, being extensively used for fishing, swimming and boating (ranging from canoeing and rowing to residential narrow boats and tourist passenger boats). The pathways alongside the length of the river are also extensively used by walkers, runners and cyclists.
The river network therefore plays an important underpinning role to support both the local and UK economy. However, the River Thames basin faces growing pressures from a rapidly increasing population and water usage, which is likely to increase pollution loadings and water stress in future decades. These effects are likely to be exacerbated by future climate change, with predicted lower flows and droughts in the Thames region in the summer months and increased flooding in the winter (Bell et al., 2012; Johnson et al., 2009). To reduce these effects, major mitigation measures are being implemented. Diffuse pollution from agricultural activities is being targeted through schemes such as the Catchment Sensitive Farming initiative, and point source inputs have been 
reduced through large-scale investment in improved levels of sewage treatment (Kinniburgh et al., 1997), to comply with the Urban Waste Water Treatment Directive (EEC, 1991) and Water Framework Directive (CEC, 2000).

The River Thames is one of the UK's most monitored and studied rivers. Due to its importance as a source of drinking water for London, the lower River Thames has been continuously monitored for nitrate concentration stretching back to 1868 , perhaps the longest continuous water quality record in the world (Howden et al., 2010). The corresponding phosphorus record for the River Thames goes back to 1936 (Haygarth et al., 2014; Powers et al., 2016). Environment Agency regulatory monitoring of phosphorus concentrations in the River Thames since the 1970s has been used to identify the major improvements in water quality due in part to the introduction of the Urban Waste Water Treatment Directive (Kinniburgh et al., 1997).

Phosphorus and nitrogen sources and dynamics in the River Thames (Neal et al., 2010a, 2000c) and its tributaries (Bowes et al., 2012c; Jarvie et al., 2006, 2002b; Neal et al., 2000a, 2004, 2006) and how nutrients interact with river ecology (House et al., 2001; Jarvie et al., 2002a; Williams et al., 2000) have been intensively studied in recent decades. These studies were based on 1- to 2-year periods of weekly monitoring by the Centre for Ecology and Hydrology (CEH), based at a small number of individual study sites, carried out between 1997 and 2008. These data are freely available from the CEH Environmental Information Data Centre portal at https://catalogue.ceh.ac.uk/documents/8e23a86b-6b544564-9789-23f4b4e045ea (last access: 15 November 2017) (Neal et al., 2012). Extensive biological surveys of phytoplankton (Lack, 1971; Lack and Berrie, 1976), macrophytes (Flynn et al., 2002), macroinvertebrates (Wright et al., 2002), zooplankton (May and Bass, 1998) and fish stocks (Mann et al., 1972) have also been conducted across the catchment since the 1960s.

The above studies were based on monitoring of a limited numbers of sites for 1- to 2-year durations. Therefore, step changes in water quality were often missed, and it was not possible to determine if observed changes in water quality were due to basin-wide conditions (such as weather conditions) or a specific change in catchment land use and management. Therefore, there was a strategic need to conduct continuous water quality monitoring at multiple sites across the Thames catchment, covering a large range of water quality determinands. The resulting monitoring platform was the CEH Thames Initiative. A weekly temporal resolution was adopted, as this was deemed appropriate to capture algal blooms and a selection of high-flow events (Bowes et al., 2009). This was supplemented by hourly phosphorus auto-analyser and nitrate probe data (alongside a range of other water quality data) at individual river sites (Bowes et al., 2015a; Halliday et al., 2015) (data freely available from the CEH Environmental Information Data Centre portal at https://catalogue.ceh.ac.uk/documents/db695881-eabe- 416c-b128-76691b2104d8, 12 April 2017) (Bowes et al., $2015 \mathrm{~b}, \mathrm{c})$. Secondly, the spatial resolution of the monitoring platform needed to cover the impacts of a range of river sizes, land use types and management options. Therefore, the Thames Initiative consists of sites along the length of the freshwater Thames, plus its major tributary subcatchments. The third feature of the Thames Initiative was that it would characterise aquatic ecology (particularly phytoplankton and bacterioplankton communities) at the same weekly frequency as the water chemistry, using flow cytometry (Read et al., 2014). The fourth feature of the Thames Initiative was that it needed to develop into a long-term (decadal) project, to identify water quality impacts in response to land use change, population pressure, sewage treatment works (STWs) improvements and variations in climate.

Since its commencement in March 2009, the Thames Initiative data have been used to quantify nutrient dynamics (Bowes et al., 2015a; Skeffington et al., 2015; Wade et al., 2012), nutrient sources (Bowes et al., 2014), phytoplankton dynamics (Bowes et al., 2012a, 2016; Read et al., 2014) and bacterioplankton biodiversity (Read et al., 2015). The resulting data sets have been extensively used as a modelling resource (Bussi et al., 2017, 2016; Hutchins et al., 2016; Whitehead et al., 2015). Other studies have used the Thames Initiative monitoring sites as a framework for investigations of organic pollutants (Nakada et al., 2017; Singer et al., 2014), heavy metals (Turner et al., 2014), emerging contaminants (Horton et al., 2017) and antimicrobial resistance (Amos et al., 2015).

The objective of this paper is to present an overview of the comprehensive data produced by the Thames Initiative research platform, detailing how samples were taken and analysed, and providing a general description of the spatial and temporal patterns in water quality. We also provide some new basic interpretation of the data, to enable future users of the data to place their studies within this basic framework.

\section{Sampling and analytical methodology}

\subsection{Design of monitoring programme}

The River Thames was monitored at weekly intervals at seven points along its length, extending from the upper Thames in the Cotswold Hills (at Hannington Wick, $46 \mathrm{~km}$ from the source) to Runnymede ( $23 \mathrm{~km}$ upstream of the tidal limit), covering a monitored reach of $189 \mathrm{~km}$. In the lower reach, just upstream of the town of Slough, some of the water of the River Thames is channelled along the Jubilee River, which is an artificial, engineered channel that is used for flood defence for the towns of Maidenhead and Windsor. One of the seven River Thames monitoring sites is on this Jubilee River, just before it rejoins the River Thames. In addition, 15 of the major tributaries entering this monitored stretch of the River Thames were also monitored. Sites were selected to be easily accessible by road (at road bridges wherever possible, 


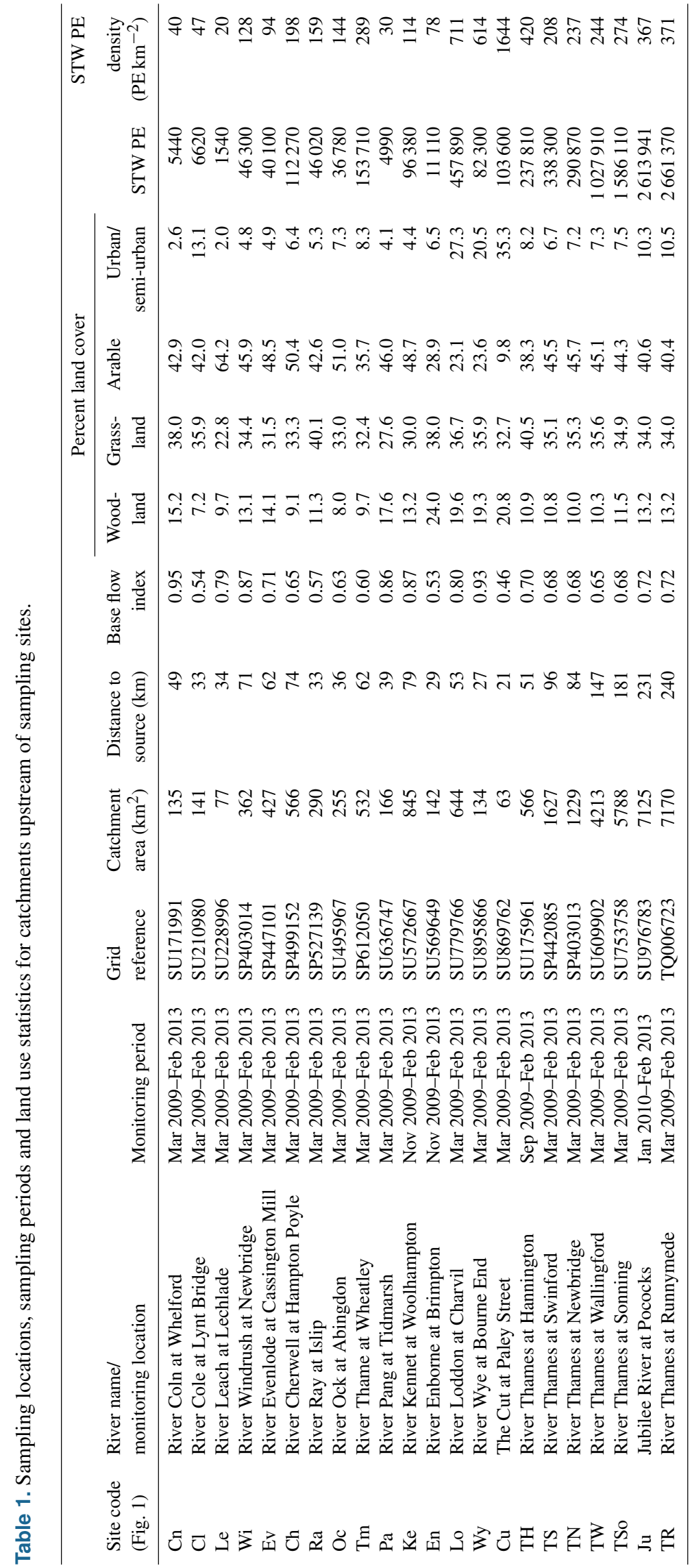




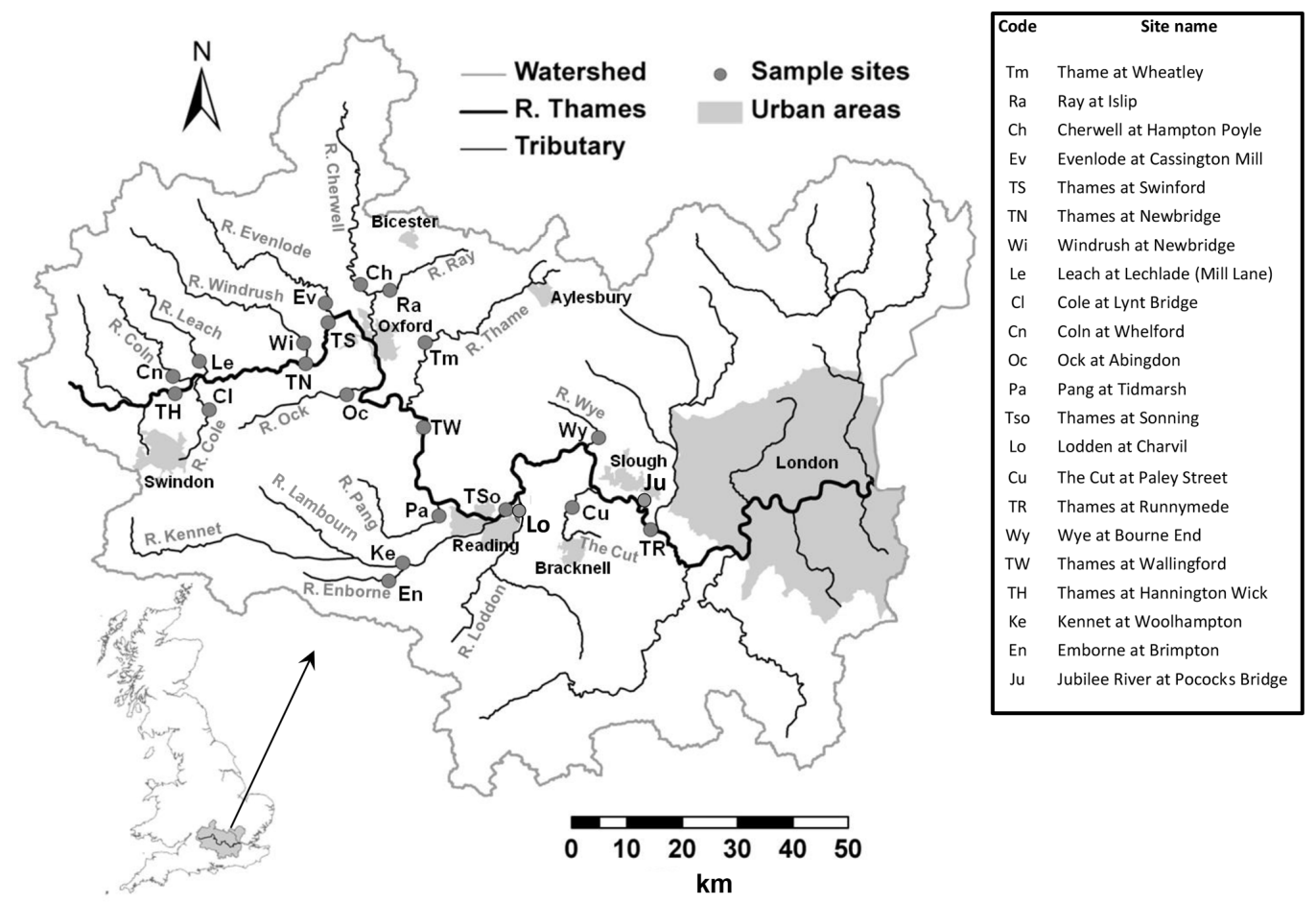

Figure 1. Location of monitoring locations across the River Thames basin.

to allow sampling from the middle of the river) and close to their confluences with the River Thames. The locations of the sampling sites are given in Table 1 and Fig. 1. Most monitoring sites were located at, or very near to, Environment Agency flow gauging stations. The monitoring programme began at most sites at the beginning of March 2009, with monitoring of the River Thames at Hannington Wick commencing in October 2009, the rivers Kennet and Enborne in November 2009, and the Jubilee River in January 2010. Data are presented up to the end of February 2013, although the monitoring programme is ongoing. Only data from 2009 to 2013 are currently freely available and discussed in this paper, but data generated within the project after 2013 will be made available through the CEH EIDC portal in the near future.

\subsection{River sampling}

Bulk samples were taken from the main flow of each river, using a plastic bucket on a rope. The bucket was rinsed twice with the local river water prior to sampling, to avoid crosscontamination between sites. Sampling of the sites took place on either Monday or Tuesday of each week. The bulk samples were immediately subsampled into two $500 \mathrm{~mL}$ bottles for suspended solids and chlorophyll analysis, an ambercoloured glass bottle (filled to the brim and sealed to minimise degassing) for $\mathrm{pH}$ and alkalinity determinations, and into $60 \mathrm{~mL}$ bottles for total metals and total phosphorus (TP) analysis. Other subsamples were filtered immediately in the field through a $0.45 \mu \mathrm{m}$ cellulose nitrate (Whatman WCN grade; Maidstone, UK) membrane filter into $60 \mathrm{~mL}$ bottles, for dissolved metals, nutrients, anions and cations analysis. All bottles were acid-washed prior to use. The water temperature of the bulk river water sample was measured in the field using an ATP multi-thermo digital thermometer (ATP Instrumentation Ltd; Ashby-de-la-Zouch, UK). Samples were stored in the dark until returned to the laboratory (within $6 \mathrm{~h}$ ).

\subsection{Analytical methods}

On return to the laboratory, all samples were stored in the dark at $4{ }^{\circ} \mathrm{C}$, prior to analysis. The $\mathrm{pH}$ was determined using a Radiometer Analytical PHM210 pH meter. The instrument was calibrated prior to use using $\mathrm{pH} 4,7$ and 10 buffer solutions traceable to National Institute of Standards and Technology (Gaithersburg, USA). Gran alkalinity was determined by acidimetric titration to $\mathrm{pH} 4$ and 3 using $0.5 \mathrm{~N} \mathrm{H}_{2} \mathrm{SO}_{4}$. Suspended solids concentrations were determined by filtering a known volume (approximately $500 \mathrm{~mL}$ ) of river water through a pre-dried Whatman $\mathrm{GF} / \mathrm{C}$ filter paper. The filter paper was then re-dried $\left(16 \mathrm{~h}\right.$ at $\left.80^{\circ} \mathrm{C}\right)$ and reweighed to determine the mass of solids in the water sample. Chlorophyll concentrations were determined by filtering a known volume of unfiltered river water (approximately $500 \mathrm{~mL}$ ) through a Whatman GF/C filter paper. The filter paper was then extracted in $10 \mathrm{~mL}$ of $90 \% v / v$ acetone/water and refriger- 
ated overnight at $4{ }^{\circ} \mathrm{C}$ in the dark. Chlorophyll- $a$ concentration was determined colorimetrically using a Beckman 750 DU spectrophotometer, using the method of Marker et al. (1980). Chlorophyll analysis was completed within $48 \mathrm{~h}$ of sampling, to avoid errors due to sample stability. Total phosphorus and total dissolved phosphorus (TDP) were determined by digesting an unfiltered and $0.45 \mu \mathrm{m}$ filtered water sample (respectively) with acidified potassium persulfate in an autoclave at $121^{\circ} \mathrm{C}$ for $45 \mathrm{~min}$. Acidified ammonium molybdate reagent was then added to the digested samples to produce a molybdenum-phosphorus complex. This intensely blue-coloured compound was then quantified spectrophotometrically at $880 \mathrm{~nm}$ (Eisenreich et al., 1975). Soluble reactive phosphorus (SRP) concentrations were determined on a filtered $(0.45 \mu \mathrm{m}$ WCN-grade cellulose nitrate membrane; Whatman, Maidstone, UK) sample, using the phosphomolybdenum-blue colorimetry method of Murphy and Riley (1962), as modified by Neal et al. (2000b), using a Seal AutoAnalyzer 3 (Seal Analytical; Fareham, UK). SRP samples were analysed within $48 \mathrm{~h}$, to minimise errors associated with sample instability. Prior to 16 August 2010, dissolved reactive silicon concentrations were determined by reaction with acid ammonium molybdate, to form yellow molybdosilicic acids. These were then reduced using an acidified tin (II) chloride solution to form intensely coloured silicomolybdenum blues, which were quantified spectrophotometrically using a Seal AutoAnalyzer 2 (Seal Analytical; Fareham, UK) (Mullin and Riley, 1955). From $16 \mathrm{Au}-$ gust 2010 onwards, dissolved reactive silicon was determined by addition of acid ammonium molybdate, to again form yellow-coloured molybdosilicic acids, and then oxalic acid was added (to eliminate phosphate interference) followed by ascorbic acid to reduce the yellow compound to molybdenum blue, which was quantified using a Seal AutoAnalyzer 3 spectrophotometer (Skougstad et al., 1978). Ammonium concentration was determined using an indophenolblue colorimetric method (Leeks et al., 1997) using a Seal AutoAnalyzer 3. Dissolved organic carbon (DOC) and total dissolved nitrogen were analysed by thermal oxidation using a Thermalox analyser (Analytical Sciences Ltd; Cambridge, UK) until December 2010 and with an Elementar Vario Cube (Elementar Analysensysteme GmbH; Langenselbold, Germany) from June 2011. There are large gaps in the DOC data set between May 2010 and May 2011, due to instrument breakdowns. Major dissolved anion (fluoride, chloride, bromide, nitrite, nitrate and sulfate) concentrations were determined by ion chromatography (Dionex AS50, Thermo Fisher Scientific; Waltham, USA). Total and dissolved cation concentrations were determined on unfiltered and filtered samples respectively, by acidification, followed by analysis by inductively coupled plasma optical emission spectrometry (ICP-OES)(Perkin Elmer Optima 2100; Seer Green, UK).

\subsection{Quality control procedures}

All chemical analyses (with the exception of suspended solids, chlorophyll and alkalinity) were carried out alongside calibration standards produced by the Wallingford Nutrient Chemistry Laboratories, using externally calibrated pipettes and balances traceable to reference standards. In addition, each batch of samples was run alongside an Aquacheck quality control standard of unknown concentration (LGC Standards, Teddington, UK). The measured concentrations of these standard Aquacheck samples were then provided to LGC Standards, who confirmed the assigned value for the sample. This "blind test" confirmed that the laboratory results were consistently close to the assigned value in terms of $z$ score (also known as standard score) throughout the period from 2009 to 2013, and well within their range of satisfactory results set by LGC $(z=\leq 2)$. The Aquacheck scheme is accredited by the United Kingdom Accreditation Service and conforms to ISO/IEC 17043.

Information of the limits of quantification for each determinand within this study, determined by Neal et al. (2012), and information on data accuracy and uncertainty are presented in Table S1 in the Supplement. Occasionally, batches failed the internal quality control procedure $(>10 \%$ from the assigned value). These batches were rerun within a day or two, until the QC standards were met. If QC standards were unable to be met due to instrument problems, and the sample was not able to be analysed before sample degradation became an issue, then the data were omitted from the data set. After analysis, samples were stored in the dark at $4{ }^{\circ} \mathrm{C}$ until all data had been checked. Questionable data points/outliers were identified and these samples were reanalysed to determine if the unexpected result was correct.

\subsection{River flow data}

The water quality data sets are presented alongside the mean daily river flows for the sites on the day of sampling. The mean daily flow data were downloaded from the National River Flow Archive (NRFA, http://nrfa.ceh.ac.uk/, last access: 3 January 2017) in January 2017. Most sites were colocated at, or very close to, Environment Agency flow gauging stations. The exceptions were the River Kennet (flow gauging data taken from Theale, approximately $5 \mathrm{~km}$ downstream of the water quality sampling site at Woolhampton) and The Cut (flow gauging data taken from Binfield, which is approximately $6 \mathrm{~km}$ upstream of the water quality sampling site of Paley Street). The other exceptions were along the River Thames itself. The Thames water quality monitoring sites at Hannington Wick, Newbridge, Wallingford and Sonning had their mean daily flows estimated by interpolation of adjacent River Thames flow gauging sites data, adjusted based on the catchment area of the water quality sampling site (Bowes et al., 2014). 
Table 2. Mean water quality data from March 2009 to February 2013.

\begin{tabular}{|c|c|c|c|c|c|c|c|c|c|}
\hline Monitoring site & $\begin{array}{r}\text { Daily river } \\
\text { discharge }\end{array}$ & $\begin{array}{r}\text { Water } \\
\text { temperature } \\
\left(\mathrm{m}^{3} \mathrm{~s}^{-1}\right)\end{array}$ & $\begin{array}{r}\mathrm{pH} \\
\left({ }^{\circ} \mathrm{C}\right)\end{array}$ & $\begin{array}{r}\text { Alkalinity } \\
\left(\mathrm{mEqL}^{-1}\right)\end{array}$ & $\begin{array}{r}\text { Suspended } \\
\text { solids } \\
\left(\mathrm{mg} \mathrm{L}^{-1}\right)\end{array}$ & $\begin{array}{r}\text { Dissolved } \\
\text { fluoride } \\
\left(\mathrm{mg} \mathrm{L}^{-1}\right)\end{array}$ & $\begin{array}{r}\text { Dissolved } \\
\text { chloride } \\
\left(\mathrm{mg} \mathrm{L}^{-1}\right)\end{array}$ & $\begin{array}{r}\text { Dissolved } \\
\text { bromide } \\
\left(\mathrm{mg} \mathrm{L}^{-1}\right)\end{array}$ & $\begin{array}{r}\text { Dissolved } \\
\text { sulfate } \\
\left(\mathrm{mg} \mathrm{L}^{-1}-\mathrm{SO}_{4}\right)\end{array}$ \\
\hline River Coln at Whelford & 2.13 & 11.76 & 7.99 & 4248 & 5.4 & 0.13 & 16.7 & 0.04 & 33.7 \\
\hline River Cole at Lynt Bridge & 1.10 & 11.72 & 7.94 & 4342 & 15.0 & 0.19 & 46.5 & 0.08 & 53.4 \\
\hline River Leach at Lechlade & 0.66 & 11.40 & 7.88 & 4357 & 3.0 & 0.10 & 16.0 & 0.04 & 35.2 \\
\hline River Windrush at Newbridge & 9.75 & 12.17 & 7.97 & 4167 & 10.9 & 0.15 & 40.6 & 0.09 & 53.6 \\
\hline River Evenlode at Cassington & 3.61 & 11.32 & 7.91 & 4027 & 15.5 & 0.12 & 25.7 & 0.05 & 45.7 \\
\hline River Cherwell at Hampton Poyle & 3.70 & 11.47 & 7.91 & 4133 & 13.3 & 0.20 & 54.2 & 0.07 & 65.6 \\
\hline River Ray at Islip & 1.94 & 11.27 & 7.66 & 4096 & 9.6 & 0.18 & 63.3 & 0.11 & 94.6 \\
\hline River Ock at Abingdon & 1.52 & 11.62 & 7.99 & 4704 & 11.0 & 0.20 & 39.2 & 0.09 & 72.0 \\
\hline River Thame at Wheatley & 3.33 & 11.54 & 7.83 & 4468 & 14.0 & 0.22 & 55.4 & 0.08 & 72.0 \\
\hline River Pang at Tidmarsh & 0.53 & 10.82 & 7.90 & 4508 & 8.1 & 0.13 & 24.6 & 0.05 & 19.3 \\
\hline River Kennet at Woolhampton & 8.78 & 11.27 & 7.99 & 4503 & 9.2 & 0.12 & 23.7 & 0.05 & 20.0 \\
\hline River Enborne at Brimpton & 1.27 & 10.46 & 7.75 & 2815 & 9.4 & 0.12 & 34.7 & 0.06 & 26.3 \\
\hline River Loddon at Charvil & 5.39 & 12.15 & 7.82 & 3207 & 7.2 & 0.12 & 60.6 & 0.09 & 47.8 \\
\hline River Wye at Bourne End & 0.84 & 12.30 & 8.07 & 4594 & 13.2 & 0.11 & 42.5 & 0.06 & 20.5 \\
\hline The Cut at Paley Street & 0.38 & 12.52 & 7.58 & 2450 & 9.2 & 0.17 & 94.7 & 0.11 & 99.7 \\
\hline River Thames at Hannington & 4.84 & 11.56 & 7.88 & 3957 & 11.6 & 0.15 & 56.3 & 0.11 & 67.4 \\
\hline River Thames at Newbridge & 9.75 & 12.17 & 7.97 & 4167 & 10.9 & 0.15 & 40.6 & 0.09 & 53.6 \\
\hline River Thames at Swinford & 13.45 & 12.07 & 8.00 & 4070 & 11.5 & 0.14 & 35.4 & 0.08 & 50.2 \\
\hline River Thames at Wallingford & 33.87 & 12.69 & 8.00 & 4149 & 15.3 & 0.17 & 46.2 & 0.08 & 67.5 \\
\hline River Thames at Sonning & 41.33 & 12.31 & 7.96 & 4149 & 11.4 & 0.16 & 40.0 & 0.07 & 50.0 \\
\hline Jubilee River at Pococks & 57.66 & 13.12 & 7.95 & 4091 & 8.3 & 0.15 & 44.0 & 0.07 & 47.6 \\
\hline River Thames at Runnymede & 54.11 & 13.01 & 7.93 & 3999 & 11.7 & 0.15 & 46.5 & 0.08 & 48.9 \\
\hline
\end{tabular}

\subsection{Site characterisation}

The characteristics of each sub-catchment, upstream of each sampling point, were determined using GIS (Table 1). Catchment area and distance to river source were determined using the Flood Estimation Handbook web service (https:// fehweb.ceh.ac.uk/, last access: 6 February 2017). Land use percentage cover and total upstream STW population estimates (PEs) were determined in ARC GIS using the CEH Intelligent River Network (Dawson et al., 2002) and UK Land Cover Map 2000 (Fuller et al., 2002), using the RACQUEL web application. The PE is an estimated load to a STW based on the typical per capita biological oxygen demand (BOD) load from the population served by the STW, combined with estimated industrial BOD contributions to the works (Keller et al., 2006). Base flow index data were derived from NRFA flow data, obtained from the UK Hydrometric Register (Marsh and Hannaford, 2008).

The monitoring platform encompasses a wide range of river sizes, from short streams of less than $40 \mathrm{~km}$ in length with mean flows of less than $1 \mathrm{~m}^{3} \mathrm{~s}^{-1}$ (River Wye, Leach and Pang) to the lower reaches of the River Thames, with mean annual flows of ca. $58 \mathrm{~m}^{3} \mathrm{~s}^{-1}$ (Marsh and Hannaford, 2008) and a river length of $240 \mathrm{~km}$ at Runnymede. The monitoring programme also covers an extremely wide range of population pressures, with the Coln and Leach catchments in the Cotswolds region being very rural, with less than $3 \%$ urban and semi-urban land cover (Fuller et al., 2002). In contrast, other tributaries (The Cut and River Loddon and Wye) have $>20 \%$ urban and semi-urban land cover, as well as very high population densities connected to the wastewater treatment infrastructure ( $>500$ STW PE km${ }^{-2}$ ). The River Thames itself is impacted by sewage for the entire monitored stretch, from the large towns and cities of Swindon, Oxford, Reading and Slough, alongside hundreds of small towns and village STWs all discharging wastewater along its length.

\section{Results and discussion}

\subsection{General water quality characteristics}

Due to the chalk and limestone geology underlying most of the catchment, the River Thames and most of its tributaries have very high Gran alkalinities (in excess of $3000 \mathrm{mEq} \mathrm{L}^{-1}$ ) and high pH (mean values ranging from of 7.66 to 8.07) (Table 2). Most of the river flows are comprised of substantial groundwater inputs, with base flow index values ranging from 0.95 (River Coln) to 0.60 (River Thame) (Table 1). Some of the catchments (such as the rivers Enborne, Ray and Cole) are overlaid with clay deposits, and these rivers have lower base flow indexes of between 0.53 and 0.57 , due to increased quantities of run-off. The Cut is an artificial river that was diverted from the upper River Loddon, and it has the lowest base flow index (0.46) and also the lowest mean Gran alkalinity of $2450 \mathrm{mEq} \mathrm{L}^{-1}$. Mean suspended solids concentrations across the basin were relatively low (ranging from 3.0 to $15.5 \mathrm{mg} \mathrm{L}^{-1}$ ) (Table 2), due to the low catchment gradients and groundwater dominance of the flow regime. The lowest suspended solids concentrations were observed in the small tributaries of the Cotswolds (rivers Coln and Leach). The highest suspended solids concentrations were 


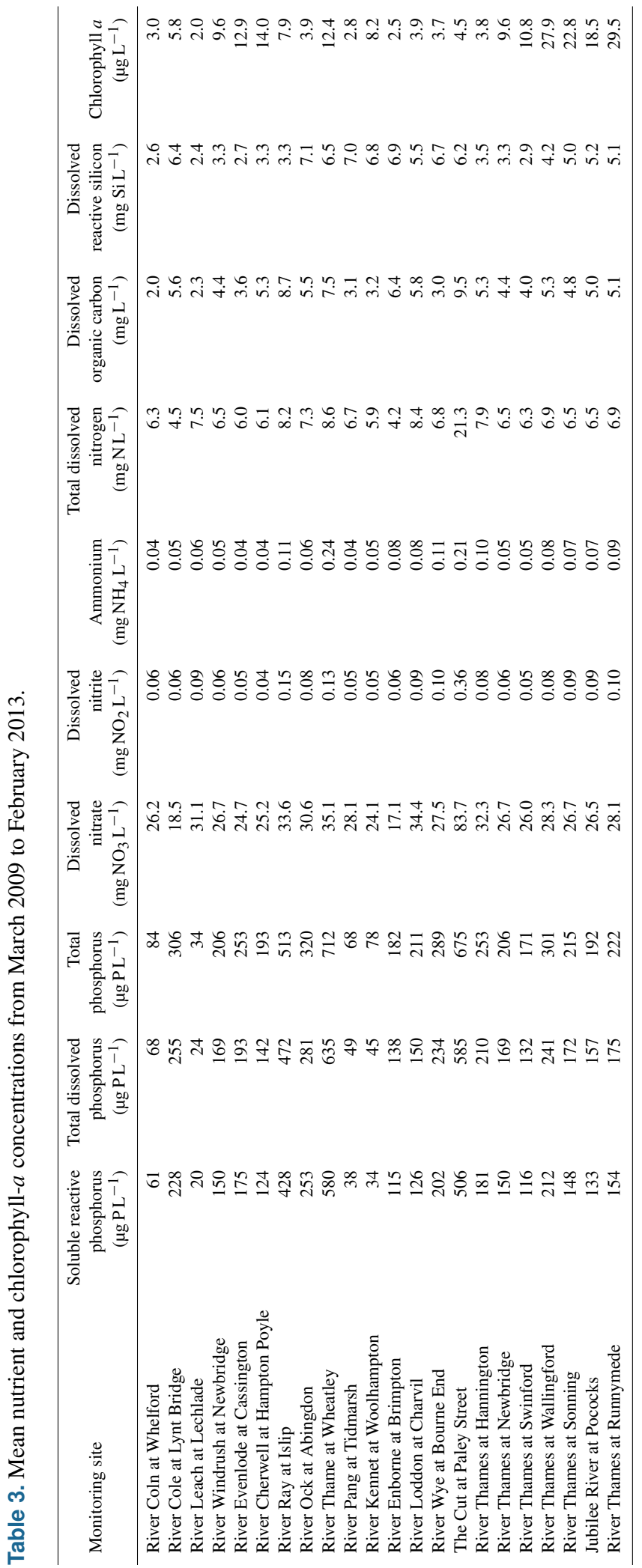

found in some of the clay-covered catchments (rivers Thame and Cole) and the steepest catchment: the River Wye. Monitoring points along the length of the River Thames and the River Cherwell also had relatively high suspended solids concentration, but much of this would be due to high phytoplankton biomass through the spring and summer, rather than sediment entrainment/soil erosion.

\subsection{Spatial data}

All monitoring sites showed significant nutrient enrichment, which reflects the high population densities across much of the catchment, the large number of STWs discharging into the River Thames and its tributaries, and relatively intensive agricultural activity in the region. A total of 18 of the 22 monitoring sites had average SRP concentrations greater than $100 \mu \mathrm{g} \mathrm{PL}^{-1}$, with the rivers Ray, Thame and Cut in excess of $400 \mu \mathrm{g} \mathrm{PL}^{-1}$ (Table 3, Fig. 2). The monitoring sites along the River Thames had relatively consistent levels of phosphorus enrichment (with mean concentrations varying from 116 to $212 \mu \mathrm{gSRPL}^{-1}$ and 171 to $301 \mu \mathrm{g} \mathrm{TPL}^{-1}$ ), due to it receiving significant STW inputs from major towns along its entire length. River Thames average phosphorus concentrations were highest in the middle reach (at Wallingford), due to its position downstream of both Oxford STW (Fig. 1) and the inputs from the phosphorus-polluted tributaries of the River Thame and Ray (Fig. 2). Only three catchments had low SRP concentrations which may be potentially limiting for primary production (Bowes et al., 2012b, 2010; McCall et al., 2017): the rivers Leach, Kennet and Pang, which had average SRP concentrations of 20,34 and $38 \mu \mathrm{g} \mathrm{PL} \mathrm{L}^{-1}$ respectively (Table 3 , Fig. 2). This is probably due to the rivers Pang and Leach having the lowest STW population equivalent densities (30 and $20 \mathrm{PE} \mathrm{km}^{-2}$ respectively), and, although the River Kennet has a higher STW-PE density $\left(114 \mathrm{PE} \mathrm{km}^{-2}\right)$, all STWs along its length have had tertiary phosphorus stripping installed (Bowes et al., 2012c), with most final effluent consents set at $<1000 \mu \mathrm{g} \mathrm{PL}{ }^{-1}$. However, these three rivers are still highly nutrient impacted, due to their very high nitrate concentrations of between 24 and $31 \mathrm{mg} \mathrm{NO}_{3} \mathrm{~L}^{-1}$.

All sites were heavily polluted with nitrate, with 20 of the 22 sites having nitrate concentrations in excess of $20 \mathrm{mg} \mathrm{NO}_{3} \mathrm{~L}^{-1}$ (Table 3, Fig. 2). This is mainly due to historic agricultural contamination of the groundwaters which commonly occurs in chalk-dominated catchments (Smith et al., 2010). Due to high catchment porosity, manures and fertilisers are easily transported from the land surface and into the groundwater aquifers. Nitrate concentrations in the lower Thames have increased from ca. $8 \mathrm{mg} \mathrm{NO}_{3} \mathrm{~L}^{-1}$ in the 1880 s to $20 \mathrm{mg} \mathrm{NO}_{3} \mathrm{~L}^{-1}$ by the 1950 s (attributed to ploughing up of grassland in the 1940s, which resulted in largescale mineralisation of organic $\mathrm{N}$ ), and increased rapidly to ca. $34 \mathrm{mg} \mathrm{NO}_{3} \mathrm{~L}^{-1}$, due to increased fertiliser applications and increasing arable land cover in the 1960s (Howden et al., 

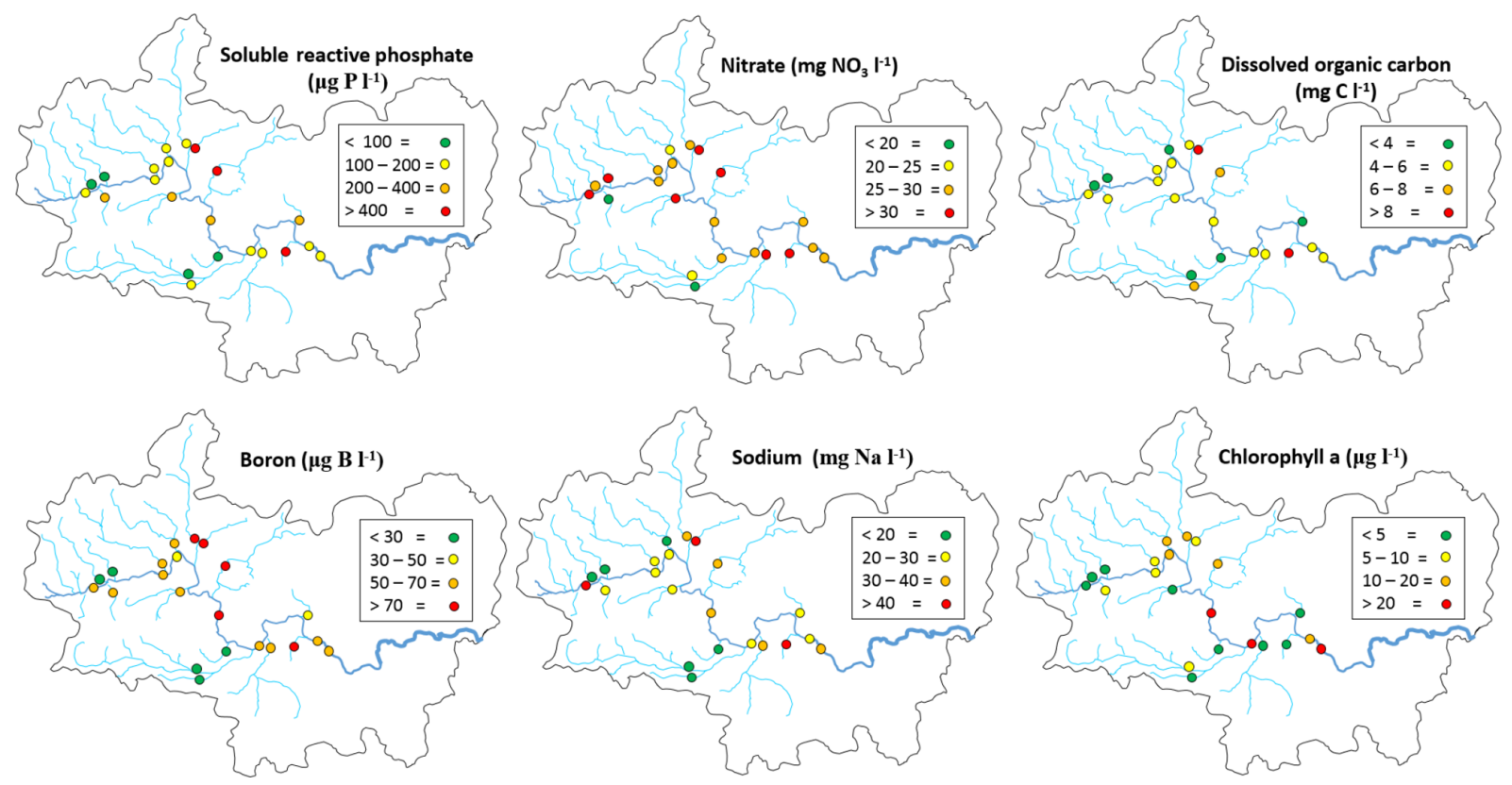

Figure 2. Spatial variation in chemical concentrations and chlorophyll $a$ across the Thames basin.

2010). By far the highest average nitrate concentration was observed in The Cut, which, at $83.7 \mathrm{mg} \mathrm{NO}_{3} \mathrm{~L}^{-1}$, was over twice as high as any of the other sites. This gross nitrate pollution is most likely due to the high sewage loading at this site (with the highest STW population density of $1644 \mathrm{PE} \mathrm{km}^{-2}$ ), as The Cut has the lowest base flow index and therefore the lowest groundwater inputs. The two other sites with the least groundwater inputs (base flow index values less than 0.54; the rivers Cole and Enborne) had the lowest average nitrate concentrations of 18.5 and $17.1 \mathrm{mg} \mathrm{NO}_{3} \mathrm{~L}^{-1}$ respectively (Fig. 2). The average ammonium concentrations also reflect sewage inputs, with the five sites with average concentrations $\geq 1.0 \mathrm{mg} \mathrm{NH}_{4}^{+} \mathrm{L}^{-1}$ (River Thames at Hannington Wick, the rivers Wye, Ray, Thame, and the Cut) all having high STW-PE densities, and many were just downstream of major sewage works.

The average DOC concentrations varied from $\leq 3 \mathrm{mg} \mathrm{CL}^{-1}$ for the relatively rural rivers in the Cotswolds (rivers Leach, Coln and Evenlode) and the area west of the town of Reading (rivers Pang and Kennet) to $\geq 8 \mathrm{mg} \mathrm{CL}^{-1}$ for the sewage-impacted River Ray and Cut. The claydominated sub-catchments of the River Enborne and Thame also had relatively high DOC concentrations $\left(>6 \mathrm{mg} \mathrm{C} \mathrm{L}^{-1}\right)$ and may reflect the higher rates of run-off that possibly wash greater quantities of organic material from the catchment into the river, compared to the other groundwater-dominated monitoring sites. The spatial pattern in the average dissolved boron concentrations also reflected the pattern in sewage inputs, with some of the most sewage-impacted tributaries (rivers Thame, Ray, Cherwell and The Cut) having concentrations in excess of $70 \mu \mathrm{g} \mathrm{BL}^{-1}$ (Table 4, Fig. 2). This is because boron is a constituent of detergents and has been used as a sewage tracer in river research in the past, although concentrations are declining rapidly due to changing detergent formulations (Neal et al., 2010b). The highest average boron concentration in the River Thames was observed in the middle reaches at Wallingford, due to its location downstream of Oxford STW and the confluences with the rivers Ray, Cherwell and Thame, all with significant boron loads. The lowest concentrations were again observed in the rural tributaries of the Cotswolds (rivers Coln and Leach) and the rivers Pang, Enborne and Kennet, west of Reading. The highest manganese, zinc and copper concentrations were observed in The Cut (Table 4), due to it having by far the highest STW population density (Table 1). Dissolved sodium concentration has a strong correlation with STW-PE density (Pearson Correlation Coefficient $=0.785$ ), indicating the element's suitability as a sewage tracer. Its spatial pattern is similar to boron concentration (Fig. 2), with highest concentrations in The Cut, Thame, Cherwell and the upper Thames downstream of Swindon STW, and lowest in the most rural sites.

The spatial pattern in average chlorophyll concentrations was in sharp contrast to the nutrient concentrations and sewage indicators described above. Highest concentrations were observed along the middle and lower reaches on the River Thames, as well as in the larger tributaries such as the Cherwell, Evenlode and Thame. There is a strong positive relationship with the distance from the monitoring point to the river source, which is probably linked with the long transit times required to develop substantial phytoplankton biomass. The spatial and temporal patterns in these chlorophyll con- 
Table 4. Mean cation concentrations from March 2009 to February 2013.

\begin{tabular}{|c|c|c|c|c|c|c|c|c|c|}
\hline Monitoring site & $\begin{array}{r}\text { Dissolved } \\
\text { sodium } \\
\left(\mathrm{mg} \mathrm{L}^{-1}\right)\end{array}$ & $\begin{array}{l}\text { Dissolved } \\
\text { potassium } \\
\left(\mathrm{mg} \mathrm{L}^{-1}\right)\end{array}$ & $\begin{array}{r}\text { Dissolved } \\
\text { calcium } \\
\left(\mathrm{mg} \mathrm{L}^{-1}\right)\end{array}$ & $\begin{array}{r}\text { Dissolved } \\
\text { magnesium } \\
\left(\mathrm{mg} \mathrm{L}^{-1}\right)\end{array}$ & $\begin{array}{r}\text { Dissolved } \\
\text { boron } \\
\left(\mu \mathrm{gL}^{-1}\right)\end{array}$ & $\begin{array}{r}\text { Dissolved } \\
\text { iron } \\
\left(\mu \mathrm{gL}^{-1}\right)\end{array}$ & $\begin{array}{r}\text { Dissolved } \\
\text { manganese } \\
\left(\mu \mathrm{gL}^{-1}\right)\end{array}$ & $\begin{array}{r}\text { Dissolved } \\
\text { zinc } \\
\left(\mu \mathrm{g} \mathrm{L}^{-1}\right)\end{array}$ & $\begin{array}{r}\text { Dissolved } \\
\text { copper } \\
\left(\mu \mathrm{gL}^{-1}\right)\end{array}$ \\
\hline River Coln at Whelford & 9 & 1.7 & 101 & 5.8 & 20 & 8 & 1.4 & 1.9 & 0.5 \\
\hline River Cole at Lynt Bridge & 28 & 5.3 & 110 & 4.4 & 56 & 48 & 10.2 & 3.5 & 1.9 \\
\hline River Leach at Lechlade & 8 & 1.5 & 109 & 5.1 & 25 & 12 & 2.6 & 1.8 & 0.6 \\
\hline River Windrush at Newbridge & 27 & 5.5 & 104 & 5.2 & 53 & 32 & 6.7 & 3.3 & 1.5 \\
\hline River Evenlode at Cassington & 16 & 3.6 & 102 & 4.2 & 51 & 48 & 6.6 & 2.4 & 1.1 \\
\hline River Cherwell at Hampton Poyle & 36 & 6.2 & 104 & 7.6 & 73 & 57 & 6.8 & 3.3 & 1.5 \\
\hline River Ray at Islip & 49 & 10.5 & 112 & 6.1 & 107 & 121 & 11.9 & 6.8 & 2.5 \\
\hline River Ock at Abingdon & 25 & 5.9 & 127 & 4.6 & 62 & 42 & 7.5 & 3.1 & 1.7 \\
\hline River Thame at Wheatley & 39 & 9.6 & 118 & 5.4 & 87 & 62 & 10.0 & 7.8 & 4.0 \\
\hline River Pang at Tidmarsh & 12 & 2.9 & 108 & 3.2 & 21 & 27 & 2.9 & 3.1 & 1.3 \\
\hline River Kennet at Woolhampton & 13 & 2.4 & 107 & 2.2 & 22 & 19 & 4.3 & 3.0 & 1.0 \\
\hline River Enborne at Brimpton & 18 & 3.6 & 68 & 4.4 & 26 & 142 & 19.6 & 3.6 & 2.2 \\
\hline River Loddon at Charvil & 39 & 7.5 & 83 & 5.3 & 57 & 74 & 17.0 & 5.9 & 2.7 \\
\hline River Wye at Bourne End & 27 & 4.3 & 107 & 1.9 & 35 & 12 & 3.7 & 8.2 & 2.7 \\
\hline The Cut at Paley Street & 71 & 13.6 & 85 & 10.1 & 89 & 91 & 13.3 & 11.0 & 7.5 \\
\hline River Thames at Hannington & 41 & 8.1 & 101 & 5.2 & 65 & 45 & 8.3 & 5.5 & 1.6 \\
\hline River Thames at Newbridge & 27 & 5.5 & 104 & 5.2 & 53 & 32 & 6.7 & 3.3 & 1.5 \\
\hline River Thames at Swinford & 23 & 4.6 & 102 & 5.0 & 47 & 28 & 5.5 & 3.0 & 1.5 \\
\hline River Thames at Wallingford & 30 & 6.5 & 109 & 5.4 & 77 & 42 & 7.1 & 4.3 & 4.0 \\
\hline River Thames at Sonning & 25 & 5.2 & 105 & 4.5 & 58 & 37 & 6.9 & 4.2 & 2.9 \\
\hline Jubilee River at Pococks & 28 & 5.4 & 102 & 4.4 & 54 & 29 & 6.1 & 4.1 & 2.8 \\
\hline River Thames at Runnymede & 30 & 5.9 & 101 & 4.6 & 61 & 32 & 5.4 & 4.8 & 2.9 \\
\hline
\end{tabular}

centration data across the Thames catchment are discussed at length in Bowes et al. (2012a).

\subsection{Temporal data}

The time series plots for the lower River Thames at Runnymede are presented as an example in Figs. 3-5, demonstrating the continuous nature of the data. The data sets from all other sites are equally complete.

\subsubsection{Physical data}

River water temperature follows a relatively consistent pattern of highest temperatures in the August of each year, and lowest temperatures occur between December and February (Fig. 3). The $\mathrm{pH}$ data vary between 7.6 and 8.2, reflecting the alkaline bedrock throughout the catchment. It is important to note that previous high-frequency monitoring of rivers across the Thames catchment have shown marked diurnal $\mathrm{pH}$ fluctuations of up to $0.6 \mathrm{pH}$ units (Halliday et al., 2014, 2015), and therefore caution should be exercised when using data from weekly manual samples. The Gran alkalinity was high (mean $=3999 \mathrm{mEq} \mathrm{L}^{-1}$ ), due to the chalk and limestone bedrock. Short-term reductions in $\mathrm{Ca}$ and alkalinity (to below $70 \mathrm{mg} \mathrm{Ca} \mathrm{L}^{-1}$ and $2600 \mathrm{mEq} \mathrm{L}^{-1}$ ) in the Thames at Runnymede coincided with peaks in chlorophyll concentrations in 2009, 2011 and 2012 (Fig. 3). During algal blooms high rates of photosynthesis result in depletion of dissolved carbon dioxide and calcium carbonate precipitation can occur (Hartley et al., 1995; Neal et al., 2002), resulting in re- ductions in alkalinity and Ca concentration within the water column. Suspended solid concentrations were highest during periods of high flow, due to a combination of soil erosion inputs during the wet winter and spring periods, as well as the resuspension of bed sediment within the river channel. Suspended solid concentration peaks in the lower River Thames also coincided with peaks in chlorophyll concentration, indicating that phytoplankton biomass provided a significant proportion of the suspended solids load during spring-summer algal blooms. Peaks in chlorophyll concentrations occurred between April and June of each year, but the magnitude and duration of chlorophyll peaks varied greatly between years. The timing and magnitude of blooms has been shown to be related to SRP and dissolved silicon concentrations, sunlight duration, river flow and water temperature, and is fully described in Bowes et al. (2016). The largest and sustained chlorophyll peaks are observed in (i) the middle and lower Thames sites and (ii) the longer tributaries (River Cherwell, River Thame), especially those connected to canal systems, indicating the importance of residence time (Bowes et al., 2012a). The river flow data shows a regular pattern, typical of UK rivers, of highest flows over the winter-spring periods (December to February) and lowest flows in July to October. However, the data set also captures a winter drought in 2011-2012, followed by uncharacteristic flooding in summer 2012. 

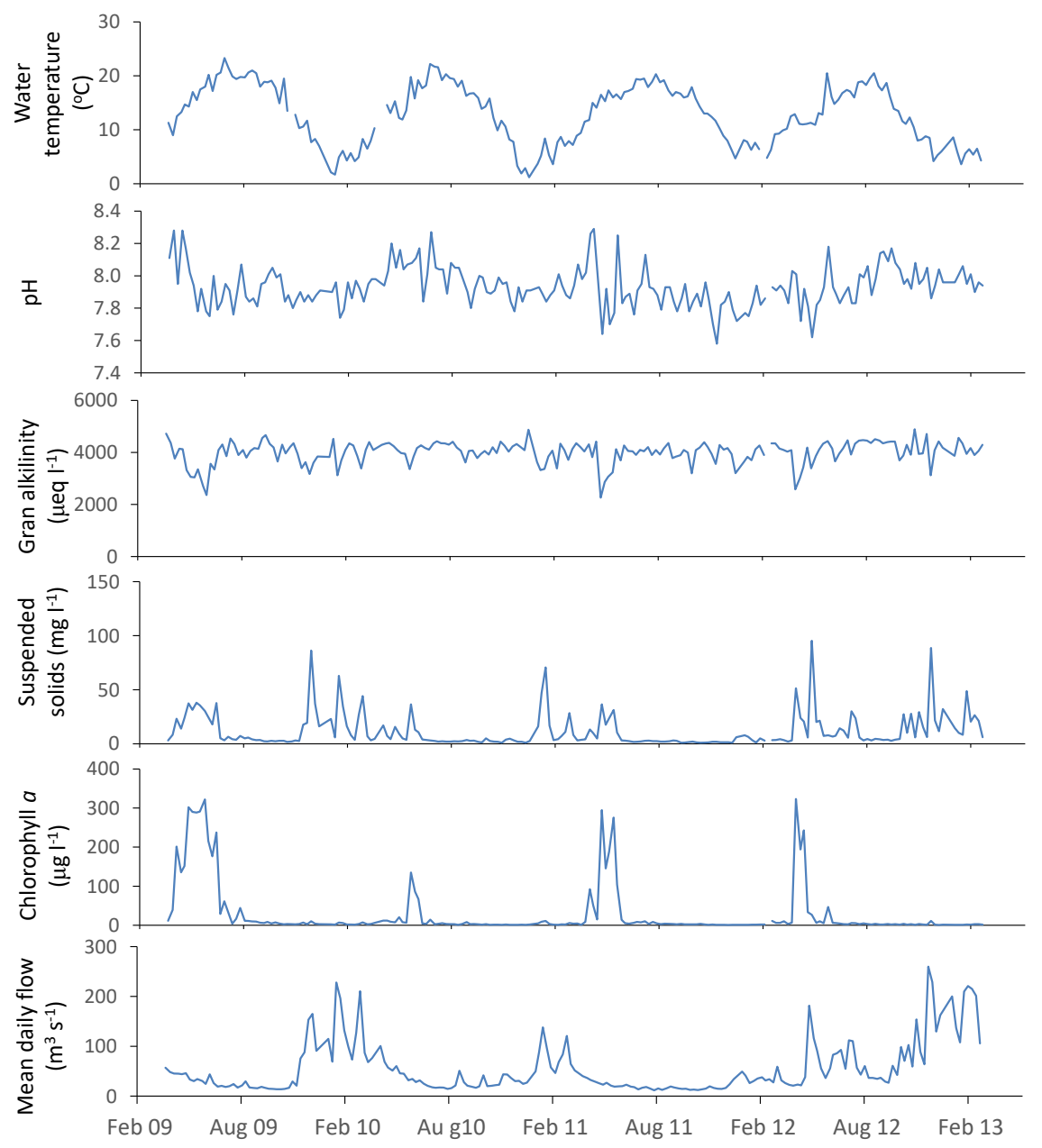

Figure 3. General water quality time series data for the downstream extent of the monitoring platform (River Thames at Runnymede).

\subsubsection{Nutrient data}

Phosphorus in the River Thames at Runnymede was predominantly in SRP form (Fig. 4), indicating the dominance of sewage effluent inputs to the River Thames and many of its tributaries. However, during periods of high chlorophyll concentrations in 2009, 2011 and 2013, SRP concentrations reduced to below $20 \mu \mathrm{g} \mathrm{L}^{-1}$ while TP was maintained at ca. $200 \mu \mathrm{g} \mathrm{L}{ }^{-1}$, indicating that dissolved phosphorus was being sequestered by the rapidly growing phytoplankton biomass (thereby becoming particulate phosphorus). The two highest peaks in TP concentration (30 April and 26 November 2012; Fig. 4) correspond with the two highest suspended solids concentrations (Fig. 3), occurring during the major storm that ended the 2011-2012 winter drought and the highest recorded river flow respectively. This indicates that there were major inputs of particulate-bound phosphorus from the catchment during these storm events, particularly following dry antecedent conditions. Nitrate concentrations remained high throughout the monitoring period, as a result of the gross pollution of groundwater aquifers typical of English chalk catchments (Smith et al., 2010). Small decreases in nitrate concentration coincided with flow peaks, indicating that these high nitrate inputs from groundwater were being diluted by rainwater/surface run-off inputs to the River Thames. Other more-sustained declines in nitrate concentrations coincided with periods of high chlorophyll concentrations and SRP depletion in spring of 2009 and 2011, due to $\mathrm{N}$ uptake by phytoplankton. Dissolved reactive silicon also depleted to below $1 \mathrm{mg} \mathrm{L}^{-1}$ during these phytoplankton blooms, indicating that diatoms (with their silicon frustules) were the major component of algal biomass. Nitrite concentrations were consistently low $\left(<0.05 \mathrm{mg} \mathrm{NO}_{2}^{-} \mathrm{L}^{-1}\right)$, but were high during the winter drought period of 2011, possibly due to lack of dilution of sewage effluent inputs and low biological processing rates on the nitrite within the river channel at low water temperatures. The highest ammonium concentrations (up to $0.26 \mathrm{mg} \mathrm{NH}_{4}^{+} \mathrm{L}^{-1}$ ) were observed during the flooding in April 2012, probably due to in-wash of 

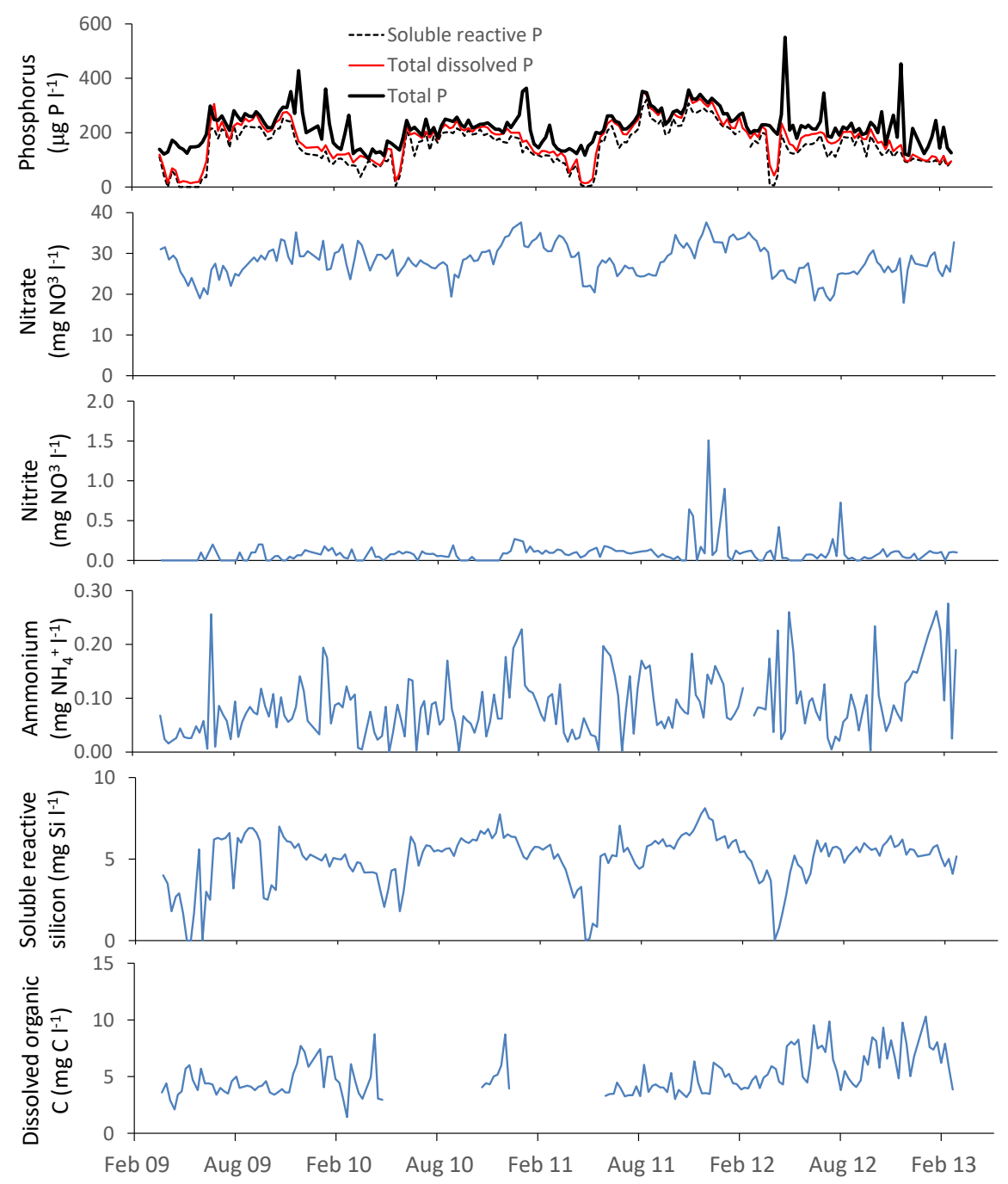

Figure 4. Nutrient concentration time series data for the downstream extent of the monitoring platform (River Thames at Runnymede).

fertilisers and manures from agricultural fields into the watercourses.

\subsubsection{Cation data}

Sodium, potassium, calcium, magnesium and boron loads in the River Thames at Runnymede were present almost entirely in dissolved form (Fig. 5). In contrast, iron was largely present in particulate form. Similar patterns were observed at all monitoring sites within this study. Sodium, potassium and to a lesser extent boron all showed sudden drops in concentration (Fig. 5) coinciding with periods of high flow (Fig. 3), indicating that their predominant sources (sewage effluent and groundwater) were being diluted by run-off and rainwater inputs. Particulate iron concentrations peaked during high flows, indicating that the predominant source was diffuse inputs from catchment soil erosion and resuspension of within-channel bed sediments. The calcium concentration data were relatively constant through the monitoring period, at ca. $100 \mathrm{mg} \mathrm{CaL}^{-1}$, but there were sudden reductions in calcium concentrations to below $80 \mathrm{mg} \mathrm{L}^{-1}$ in the spring of each year, coinciding with reductions in alkalinity and periods of high chlorophyll concentrations, due to the precipitation of $\mathrm{CaCO}_{3}$, as described above (Sect. 3.3.1).

\subsection{Long-term temporal changes in nutrient concentrations}

\subsubsection{Phosphorus}

There have been no marked changes in water quality at any of the study sites over the 2009 to 2013 monitoring period of the Thames Initiative, indicating the lack of investment in sewage treatment improvements across the catchment through this period. However, com- 


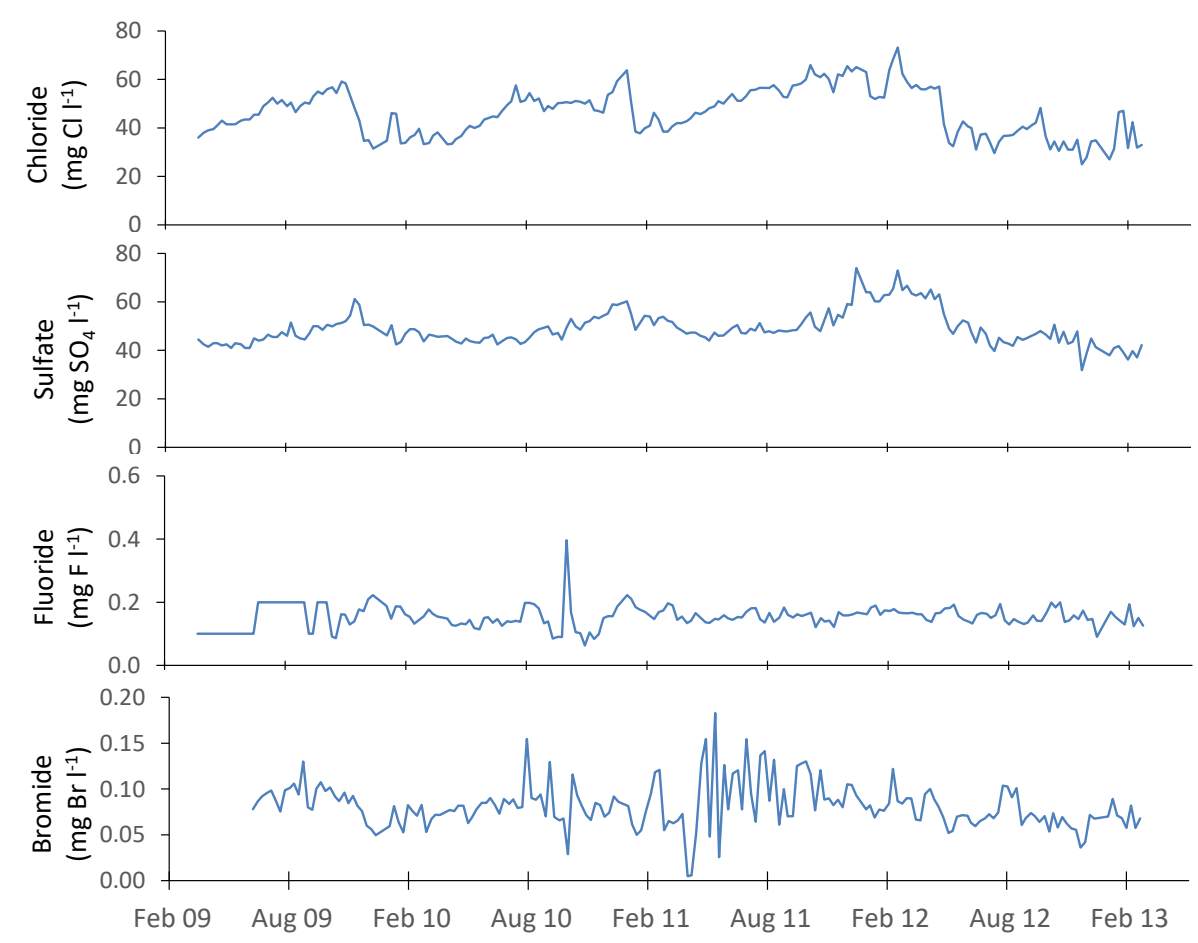

Figure 5. Cation concentration time series data for the downstream extent of the monitoring platform (River Thames at Runnymede).

parisons with past monitoring data from the same study sites (Neal et al., 2012) (https://catalogue.ceh.ac.uk/id/ 8e23a86b-6b54-4564-9789-23f4b4e045ea) have shown that there has been a major reduction in both total phosphorus and soluble reactive phosphorus concentrations since the late 1990s at most sites.

An example for the middle reach of the River Thames at Wallingford is presented in Fig. 6. Data prior to 2009 were collected from the River Thames at Howbery Park, which is approximately $200 \mathrm{~m}$ upstream of the River Thames at the Wallingford monitoring site used during the Thames Initiative research platform. There are no known inputs between these monitoring sites, and so the data from each data set were equivalent. There is a major step reduction in SRP in 1998, and another reduction between 2002 and 2006 (Fig. 6a), although the exact timing of this is unknown, as the monitoring data prior to the start of the Thames Initiative are not continuous. The Thames basin has been the focus for many mitigation measures aimed at reducing sewage effluent inputs of $\mathrm{P}$ (primarily through the Urban Wastewater Treatment Directive) and reducing diffuse $\mathrm{P}$ pollution from farming (e.g. through the Catchment Sensitive Farming initiative and adoption of agri-environment schemes). The sudden reduction in SRP concentration in winter of 1998-1999 (halving the maximum annual SRP concentration from ca. 1800 to $800 \mu \mathrm{g} \mathrm{SRP} \mathrm{L}^{-1}$ ) strongly suggests that there were major interventions at this time, rather than the multiple small agricultural interventions. The relationship between SRP con- centration and flow (Fig. 6b) clearly shows that the reductions in SRP concentrations in both winter 1998 and prior to 2006 occurred during low-flow periods. Again, this strongly suggests that it is a constant $P$ input (i.e. sewage effluent) that has been reduced, rather than rain-related agricultural inputs (Bowes et al., 2008). This is further confirmed by plotting the SRP concentrations against sodium concentration (a conservative sewage marker) (Neal et al., 2010b) (Fig. 6b), which shows that the $80 \%$ reduction in SRP (from an average of $1016 \mu \mathrm{g} \mathrm{L}^{-1}$ in $1997-1998$ to an average of $212 \mu \mathrm{g} \mathrm{L}-1$ in 2009-2013) is predominantly due to reductions in sewage effluent phosphorus loadings. This is further backed up by information on the implementation of the Urban Wastewater Treatment Directive within the catchment, which introduced phosphorus stripping at all STWs greater than 10000 population equivalent (between 1996 and March 2008).

However, these data sets also show that there has been little improvement in phosphorus concentrations in the River Thames and its tributaries since February 2009. A previous study of the Thames Initiative data using Load Apportionment Modelling (Bowes et al., 2014) has highlighted that despite past improvements (due largely to the introduction of phosphorus stripping at sewage treatment works), the Thames and most tributaries are still dominated by STW P inputs. The most effective strategy to further reduce $\mathrm{P}$ concentrations across the catchment would be to focus resources at further reductions in point source inputs from STWs, rather than diffuse agricultural mitigation, especially as these 

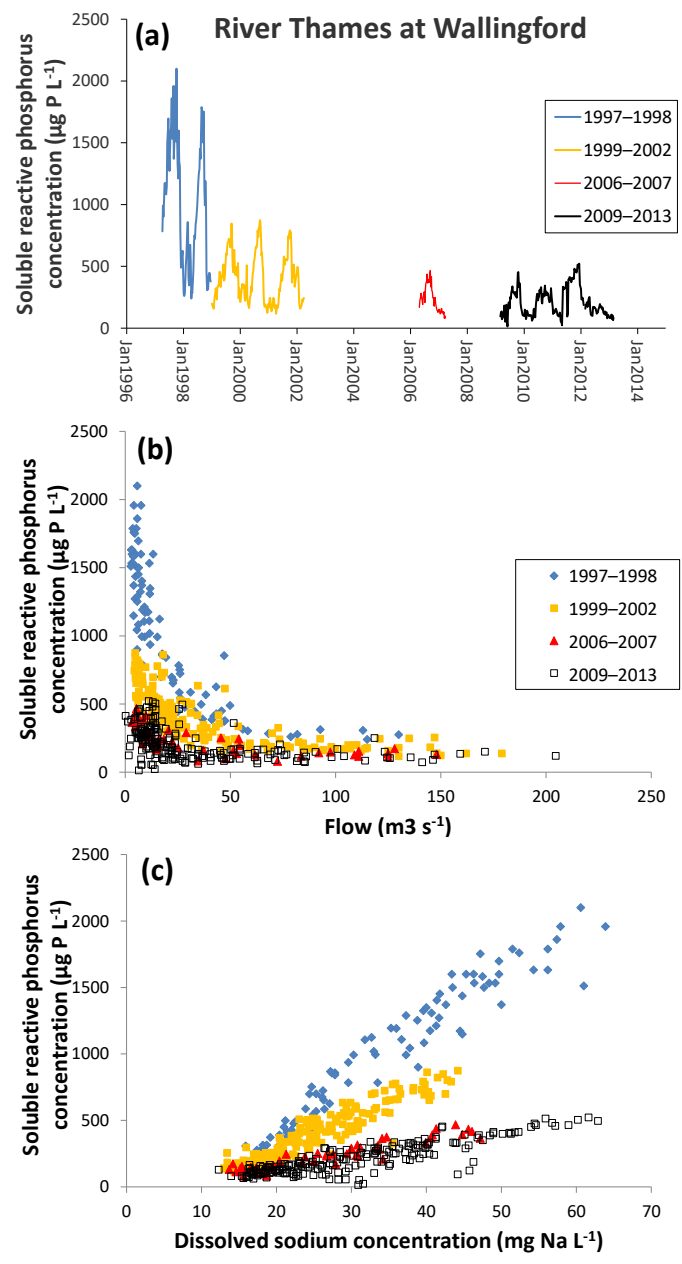

Figure 6. Changes in soluble reactive $\mathrm{P}$ concentration in the middle reaches of the River Thames at Wallingford from 1997 to 2013, as (a) a time series, (b) related to mean daily river flow and (c) related to sodium concentration.

data sets clearly show that STW improvements have a major and immediate impact on river water quality.

\subsubsection{Nitrate}

The 140-year nitrate concentration data record of the lower River Thames by Howden et al. (2010) showed that nitrate concentrations have increased from $<2 \mathrm{mg} \mathrm{NO}_{3}-\mathrm{NL}^{-1}$ in the late $1860 \mathrm{~s}$ and $1870 \mathrm{~s}$ and reached a maximum of $>7 \mathrm{mg} \mathrm{NO}_{3}-\mathrm{NL}^{-1}$ from the late 1970 s to 1990 s. Since 2000, the average nitrate concentrations in the lower River Thames decreased slightly to ca. $6.8 \mathrm{mg} \mathrm{NO}_{3}-\mathrm{NL}^{-1}$, suggesting that nitrate concentrations were beginning to decline. The Thames Initiative data further support this observation, showing that the average nitrate concentration in the lower River Thames at Runnymede (2009-2013) was $28.1 \mathrm{mg} \mathrm{NO}_{3} \mathrm{~L}^{-1}$ (Table 3), which is equivalent to $6.35 \mathrm{mg} \mathrm{N} \mathrm{L}^{-1}$.
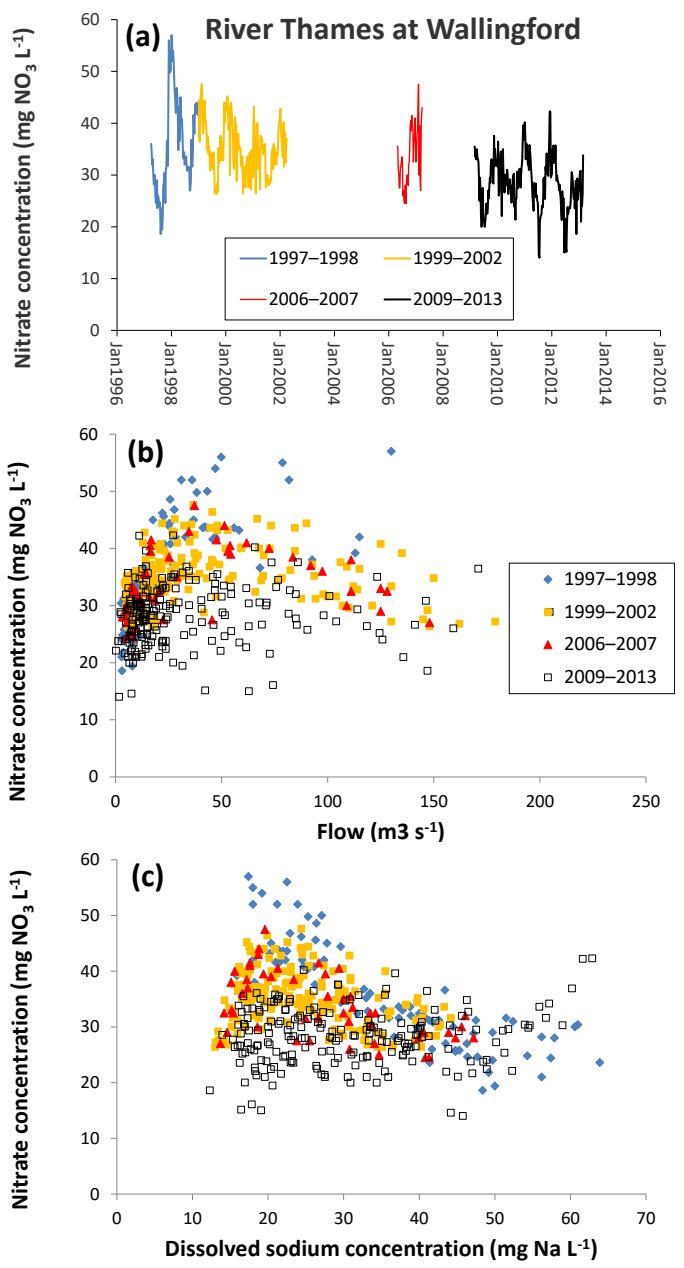

Figure 7. Changes in nitrate concentration in the middle reaches of the River Thames at Wallingford from 1997 to 2013, as (a) a time series, (b) related to mean daily river flow and (c) related to sodium concentration.

Combining the CEH data sets from 1997 to 2008 and the CEH Thames Initiative data (2009-2013) provides good evidence that nitrate concentrations have reached a turning point and are beginning to slowly decline. The middle River Thames at Wallingford shows nitrate concentrations peaking in 1998 and gradually reducing throughout the following years (Fig. 7a). Nitrate concentrations showed little change over time at low flows $\left(<25 \mathrm{~m}^{3} \mathrm{~s}^{-1}\right)$ but were declining at medium to high flows (25 to $150 \mathrm{~m}^{3} \mathrm{~s}^{-1}$ ) (Fig. $7 b$ ), suggesting that there is a reduction in diffuse, rain-related nitrate sources, but not constant inputs such as STWs. This is further supported by examining the relationship between nitrate and sodium concentration. At high sodium concentration $>40 \mathrm{mg} \mathrm{L}^{-1}$ (indicating high sewage inputs) nitrate concentrations from the different monitoring periods are all relatively similar (Fig. 7c). When sodium concentrations are lower (particularly ca. $20 \mathrm{mg} \mathrm{L}^{-1}$ ), there has been a clear 
reduction in nitrate concentration throughout the monitoring periods. These observations suggest that the reduction in river nitrate concentration is due to reduced inputs from diffuse, rain-related sources such as agriculture run-off or groundwater nitrate concentration, and not due to reduced loadings from sewage effluent.

\section{Data availability}

The entire data set presented in this study is freely available through the Centre for Ecology and Hydrology's Environmental Information Data Centre data portal https://catalogue. ceh.ac.uk/eidc/documents. The data set is titled "Weekly water quality data from the River Thames and its major tributaries (2009-2013) [CEH Thames Initiative]". The digital object identifier is https://doi.org/10.5285/e4c300b1-8bc34df2-b23a-e72e67eef2fd (Bowes et al., 2017).

\section{Conclusions}

This catchment-wide biogeochemical monitoring platform provides the research community with a valuable data resource for furthering our understanding of pollution sources and dynamics, biological interactions, impacts of land use and increasing population pressures across this internationally known river catchment. The CEH Thames Initiative data can be linked with previous (non-continuous) monitoring data sets from many common study sites, dating back to 1997 , and hourly physical and chemical data sets from two of its tributaries. This ongoing monitoring programme will continue to capture the impacts of increasing population densities, changes in agricultural practices and the impacts of improved sewage treatment processes, which have important implications for the sustainability of London and the UK economy.

Supplement. The supplement related to this article is available online at: https://doi.org/10.5194/essd-10-1637-2018-supplement.

Author contributions. Sample collection and initial preparation were undertaken by PS and CR. All laboratory analysis was carried out by HW, LA, SH, EG, and DN. Data curation was undertaken by MB and NB. MB wrote the paper and HPJ, GO, and DR provided important contributions and interpretation.

Competing interests. The authors declare that they have no conflict of interest.

Acknowledgements. We thank the Natural Environment Research Council, UK, for funding the monitoring programme, and staff at the Environmental Information Data Centre for managing the data and allocating a doi. We also thank Colin Neal, who provided advice when establishing the Thames Initiative platform.

Edited by: David Carlson

Reviewed by: two anonymous referees

\section{References}

Amos, G. C. A., Gozzard, E., Carter, C. E., Mead, A., Bowes, M. J., Hawkey, P. M., Zhang, L., Singer, A. C., Gaze, W. H., and Wellington, E. M. H.: Validated predictive modelling of the environmental resistome, ISME J., 9, 1467-1476, https://doi.org/10.1038/ismej.2014.237, 2015.

Bell, V. A., Kay, A. L., Cole, S. J., Jones, R. G., Moore, R. J., and Reynard, N. S.: How might climate change affect river flows across the Thames Basin? An area-wide analysis using the UKCP09 Regional Climate Model ensemble, J. Hydrol., 442443, 89-104, 2012.

Bowes, M. J., Smith, J. T., Jarvie, H. P., and Neal, C.: Modelling of phosphorus inputs to rivers from diffuse and point sources, Sci. Total Environ., 395, 125-138, 2008.

Bowes, M. J., Smith, J. T., and Neal, C.: The value of highresolution nutrient monitoring: A case study of the River Frome, Dorset, UK, J. Hydrol., 378, 82-96, 2009.

Bowes, M. J., Lehmann, K., Jarvie, H. P., and Singer, A. C.: Investigating periphyton response to changing phosphorus concentrations in UK rivers using within-river flumes. In: BHS Third International Symposium, Managing Consequences of a Changing Global Environment, Newcastle-upon-Tyne, 2010.

Bowes, M. J., Gozzard, E., Johnson, A. C., Scarlett, P. M., Roberts, C., Read, D. S., Armstrong, L. K., Harman, S. A., and Wickham, H. D.: Spatial and temporal changes in chlorophyll $a$ concentrations in the River Thames basin, UK: Are phosphorus concentrations beginning to limit phytoplankton biomass?, Sci. Total Environ., 426, 45-55, 2012a.

Bowes, M. J., Ings, N. L., McCall, S. J., Warwick, A., Barrett, C., Wickham, H. D., Harman, S. A., Armstrong, L. K., Scarlett, P. M., Roberts, C., Lehmann, K., and Singer, A. C.: Nutrient and light limitation of periphyton in the River Thames: Implications for catchment management, Sci. Total Environ., 434, 201-212, 2012 b.

Bowes, M. J., Palmer-Felgate, E. J., Jarvie, H. P., Loewenthal, M., Wickham, H. D., Harman, S. A., and Carr, E.: High-frequency phosphorus monitoring of the River Kennet, UK: are ecological problems due to intermittent sewage treatment works failures?, J. Environ. Monitor., 14, 3137-3145, 2012c.

Bowes, M. J., Jarvie, H. P., Naden, P. S., Old, G. H., Scarlett, P. M., Roberts, C., Armstrong, L. K., Harman, S. A., Wickham, H. D., and Collins, A. L.: Identifying priorities for nutrient mitigation using river concentration-flow relationships: The Thames basin, UK, J. Hydrol., 517, 1-12, 2014.

Bowes, M. J., Jarvie, H. P., Halliday, S. J., Skeffington, R. A., Wade, A. J., Loewenthal, M., Gozzard, E., Newman, J. R., and PalmerFelgate, E. J.: Characterising phosphorus and nitrate inputs to a rural river using high-frequency concentration-flow relationships, Sci. Total Environ., 511, 608-620, 2015a.

Bowes, M. J., Gozzard, E., Newman, J., Loewenthal, M., Halliday, S., Skeffington, R. A., Jarvie, H. P., Wade, A., and PalmerFelgate, E.: Hourly physical and nutrient monitoring data for The 
Cut, Berkshire (2010-2012), NERC Environmental Information Data Centre, https://doi.org/10.5285/abe4dd7c-a340-4595-a57f8c1446ff7656, 2015b.

Bowes, M. J., Gozzard, E., Newman, J., Loewenthal, M., Halliday, S., Skeffington, R. A., Jarvie, H. P., Wade, A., and PalmerFelgate, E.: Hourly physical and nutrient monitoring data for the River Enborne, Berkshire (2009-2012), NERC Environmental Information Data Centre, https://doi.org/10.5285/11d712e07456-4ea9-8af8-fe81a666e91b, 2015c.

Bowes, M. J., Loewenthal, M., Read, D. S., Hutchins, M. G., Prudhomme, C., Armstrong, L. K., Harman, S. A., Wickham, H. D., Gozzard, E., and Carvalho, L.: Identifying multiple stressor controls on phytoplankton dynamics in the River Thames (UK) using high-frequency water quality data, Sci. Total Environ., 569-570, 1489-1499, 2016.

Bowes, M. J., Armstrong, L. K., Wickham, H. D., Harman, S. A., Gozzard, E., Roberts, C., and Scarlett, P. M.: Centre for Ecology \& Hydrology, Weekly water quality data from the River Thames and its major tributaries (2009-2013) [CEH Thames Initiative], NERC Environmental Information Data Centre, https://doi.org/10.5285/e4c300b1-8bc3-4df2-b23ae72e67eef2fd, 2017.

Bussi, G., Whitehead, P. G., Bowes, M. J., Read, D. S., Prudhomme, C., and Dadson, S. J.: Impacts of climate change, land-use change and phosphorus reduction on phytoplankton in the River Thames (UK), Sci. Total Environ., 572, 1507-1519, https://doi.org/10.1016/j.scitotenv.2016.02.109, 2016.

Bussi, G., Dadson, S. J., Bowes, M. J., and Whitehead, P. G.: Seasonal and Interannual Changes in Sediment Transport Identified through Sediment Rating Curves, J. Hydrol. Eng., 22, 06016016 , https://doi.org/10.1061/(ASCE)HE.1943-5584.0001466, 2017.

CEC: Directive 2000/60/EC of the European Parliament and of the Council establishing a framework for the Community action in the field of Water Policy, Official Journal of the European Communities, European Parliament, Council of the European Union, 43, 327, ISSN 0378-6978, 2000.

Dawson, F. H., Hornby, D. D., and Hilton, J.: A method for the automated extraction of environmental variables to help the classification of rivers in Britain, Aquat. Conserv.-Mar. Freshw. Ecosyst., 12, 391-403, 2002.

EEC: Urban waste water treatment, European Economic Community, Brussels, Belgium, Directive 91/271/EEC, 1991.

Eisenreich, S. J., Bannerman, R. T., and Armstrong, D. E.: A simplified phosphorus analytical technique, Environ. Lett., 9, 45-53, 1975.

Flynn, N. J., Snook, D. L., Wade, A. J., and Jarvie, H. P.: Macrophyte and periphyton dynamics in a UK Cretaceous chalk stream: the River Kennet, a tributary of the Thames, Sci. Total Environ., 282, 143-157, 2002.

Fuller, R. M., Smith, G. M., Sanderson, J. M., Hill, R. A., and Thomson, A. G.: The UK Land Cover Map 2000: Construction of a parcel-based vector map from satellite images, Cartogr. J., $39,15-25,2002$.

Halliday, S., Skeffington, R., Bowes, M., Gozzard, E., Newman, J., Loewenthal, M., Palmer-Felgate, E., Jarvie, H., and Wade, A.: The Water Quality of the River Enborne, UK: Observations from High-Frequency Monitoring in a Rural, Lowland River System, Water, 6, 150-180, 2014.
Halliday, S. J., Skeffington, R. A., Wade, A. J., Bowes, M. J., Gozzard, E., Newman, J. R., Loewenthal, M., Palmer-Felgate, E. J., and Jarvie, H. P.: High-frequency water quality monitoring in an urban catchment: hydrochemical dynamics, primary production and implications for the Water Framework Directive, Hydrol. Process., 29, 3388-3407, 2015.

Hartley, A. M., House, W. A., Callow, M. E., and Leadbeater, B. S. C.: The Role of a Green Alga in the Precipitation of Calcite and the Coprecipitation of Phosphate in Freshwater, Internationale Revue der gesamten Hydrobiologie und Hydrographie, 80, 385 401, 1995.

Haygarth, P. M., Jarvie, H. P., Powers, S. M., Sharpley, A. N., Elser, J. J., Shen, J., Peterson, H. M., Chan, N.-I., Howden, N. J. K., Burt, T., Worrall, F., Zhang, F., and Liu, X.: Sustainable Phosphorus Management and the Need for a Long-Term Perspective: The Legacy Hypothesis, Environ. Sci. Technol., 48, 8417-8419, 2014.

Horton, A. A., Svendsen, C., Williams, R. J., Spurgeon, D. J., and Lahive, E.: Large microplastic particles in sediments of tributaries of the River Thames, UK-Abundance, sources and methods for effective quantification, Mar. Pollut. Bull., 114, 218-226, 2017.

House, W. A., Duplat, D., Denison, F. H., Henville, P., Dawson, F. H., Cooper, D. M., and May, L.: The role of macrophytes in the retention of phosphorus in the River Thame, England, Chem. Ecol., 17, 271-291, 2001.

Howden, N. J. K., Burt, T. P., Worrall, F., Whelan, M. J., and Bieroza, M.: Nitrate concentrations and fluxes in the River Thames over 140 years (1868-2008): are increases irreversible?, Hydrol. Process., 24, 2657-2662, 2010.

Hutchins, M. G., Williams, R. J., Prudhomme, C., Bowes, M. J., Brown, H. E., Waylett, A. J., and Loewenthal, M.: Projections of future deterioration in UK river quality are hampered by climatic uncertainty under extreme conditions, Hydrol. Sci. J., 61, 2818 2833, 2016.

Jarvie, H. P., Neal, C., Warwick, A., White, J., Neal, M., Wickham, H. D., Hill, L. K., and Andrews, M. C.: Phosphorus uptake into algal biofilms in a lowland chalk river, Sci. Total Environ., 282, 353-373, 2002a.

Jarvie, H. P., Neal, C., Williams, R. J., Neal, M., Wickham, H. D., Hill, L. K., Wade, A. J., Warwick, A., and White, J.: Phosphorus sources, speciation and dynamics in the lowland eutrophic River Kennet, UK, Sci. Total Environ., 282, 175-203, 2002 b.

Jarvie, H. P., Neal, C., Juergens, M. D., Sutton, E. J., Neal, M., Wickham, H. D., Hill, L. K., Harman, S. A., Davies, J. J. L., Warwick, A., Barrett, C., Griffiths, J., Binley, A., Swannack, N., and McIntyre, N.: Within-river nutrient processing in Chalk streams: The Pang and Lambourn, UK, J. Hydrol., 330, 101-125, 2006.

Johnson, A. C., Acreman, M. C., Dunbar, M. J., Feist, S. W., Giacomello, A. M., Gozlan, R. E., Hinsley, S. A., Ibbotson, A. T., Jarvie, H. P., Jones, J. I., Longshaw, M., Maberly, S. C., Marsh, T. J., Neal, C., Newman, J. R., Nunn, M. A., Pickup, R. W., Reynard, N. S., Sullivan, C. A., Sumpter, J. P., and Williams, R. J.: The British river of the future: How climate change and human activity might affect two contrasting river ecosystems in England, Sci. Total Environ., 407, 4787-4798, 2009.

Keller, V., Fox, K., Rees, H. G., and Young, A. R.: Estimating population served by sewage treatment works from readily available GIS data, Sci. Total Environ., 360, 319-327, 2006. 
Kinniburgh, J. H., Tinsley, M. R., and Bennett, J.: Orthophosphate Concentrations in the River Thames, Water Environ. J., 11, 178$185,1997$.

Lack, T. J.: Quantitative studies on the phytoplankton of the Rivers Thames and Kennet at Reading, Freshw. Biol., 1, 213-224, 1971.

Lack, T. J. and Berrie, A. D.: Phytoplankton production in the Rivers Thames and Kennet at Reading, England during 1970, Blackwell Scientific Publications, Oxford, UK, 1976.

Leeks, G. J. L., Neal, C., Jarvie, H. P., Casey, H., and Leach, D. V.: The LOIS river monitoring network: strategy and implementation, Sci. Total Environ., 194-195, 101-109, 1997.

Mann, K. H., Britton, R. H., Kowalczewski, A., Lack, T. J., Mathews, C. P., and McDonald, I.: Productivity and energy flow at all trophic levels in the River Thames England, IBP-UNESCO, Krakow, Poland, 1972.

Marker, A. F. H., Nusch, E. A., Rai, H., and Riemann, B.: The measurement of photosynthetic pigments in freshwaters and standardisation of methods: Conclusions and recommendations, Arch. Hydrobiol. Beih., 14, 91-106, 1980.

Marsh, T. J. and Hannaford, J.: UK Hydrometric Register. Hydrological data UK series, Centre for Ecology and Hydrology, 210 pp., 2008.

May, L. and Bass, J. A. B.: A study of rotifers in the River Thames, England, April-October, 1996, Hydrobiologia, 387, 251-257, 1998.

McCall, S. J., Hale, M. S., Smith, J. T., Read, D. S., and Bowes, M. J.: Impacts of phosphorus concentration and light intensity on river periphyton biomass and community structure, Hydrobiologia, 792, 315-330, https://doi.org/10.1007/s10750-016-3067$1,2017$.

Mullin, J. B. and Riley, J. P.: The colourometric determination of silicate with special reference to sea and natural waters, Anal. Chim. Acta, 12, 31-36, 1955.

Murphy, J. and Riley, J. P.: A modified single solution method for the determination of phosphorus in natural waters, Anal. Chem. Acta, 12, 31-36, 1962.

Nakada, N., Hanamoto, S., Jurgens, M. D., Johnson, A. C., Bowes, M. J., and Tanaka, H.: Assessing the population equivalent and performance of wastewater treatment through the ratios of pharmaceuticals and personal care products present in a river basin: Application to the River Thames basin, UK, Sci. Total Environ., 575, 1100-1108, 2017.

Neal, C., Jarvie, H. P., Howarth, S. M., Whitehead, P. G., Williams, R. J., Neal, M., Harrow, M., and Wickham, H.: The water quality of the River Kennet: initial observations on a lowland chalk stream impacted by sewage inputs and phosphorus remediation, Sci. Total Environ., 251, 477-495, 2000a.

Neal, C., Neal, M., and Wickham, H.: Phosphate measurement in natural waters: two examples of analytical problems associated with silica interference using phosphomolybdic acid methodologies, Sci. Total Environ., 251, 511-522, 2000b.

Neal, C., Williams, R. J., Neal, M., Bhardwaj, L. C., Wickham, H., Harrow, M., and Hill, L. K.: The water quality of the River Thames at a rural site downstream of Oxford, Sci. Total Environ., 251, 441-457, 2000c.

Neal, C., Jarvie, H. P., Williams, R. J., Neal, M., Wickham, H., and Hill, L.: Phosphorus-calcium carbonate saturation relationships in a lowland chalk river impacted by sewage inputs and phosphorus remediation: an assessment of phosphorus self-cleansing mechanisms in natural waters, Sci. Total Environ., 282-283, 295-310, 2002.

Neal, C., Jarvie, H. P., Wade, A. J., Neal, M., Wyatt, R., Wickham, H., Hill, L., and Hewitt, N.: The water quality of the LOCAR Pang and Lambourn catchments, Hydrol. Earth Syst. Sci., 8, 614-635, https://doi.org/10.5194/hess-8-614-2004, 2004.

Neal, C., Neal, M., Hill, L., and Wickham, H.: River water quality of the River Cherwell: An agricultural clay-dominated catchment in the upper Thames Basin, southeastern England, Sci. Total Environ., 360, 272-289, 2006.

Neal, C., Jarvie, H. P., Williams, R., Love, A., Neal, M., Wickham, H., Harman, S., and Armstrong, L.: Declines in phosphorus concentration in the upper River Thames (UK): Links to sewage effluent cleanup and extended end-member mixing analysis, Sci. Total Environ., 408, 1315-1330, 2010a.

Neal, C., Williams, R. J., Bowes, M. J., Harrass, M. C., Neal, M., Rowland, P., Wickham, H., Thacker, S., Harman, S., Vincent, C., and Jarvie, H. P.: Decreasing boron concentrations in UK rivers: insights into reductions in detergent formulations since the $1990 \mathrm{~s}$ and within-catchment storage issues, Sci. Total Environ., 408, 1374-1385, 2010b.

Neal, C., Bowes, M., Jarvie, H. P., Scholefield, P., Leeks, G., Neal, M., Rowland, P., Wickham, H., Harman, S., Armstrong, L., Sleep, D., Lawlor, A., and Davies, C. E.: Lowland river water quality: a new UK data resource for process and environmental management analysis, Hydrol. Process., 26, 949-960, 2012.

Powers, S. M., Bruulsema, T. W., Burt, T. P., Chan, N. I., Elser, J. J., Haygarth, P. M., Howden, N. J. K., Jarvie, H. P., Lyu, Y., Peterson, H. M., Sharpley, Andrew N., Shen, J., Worrall, F., and Zhang, F.: Long-term accumulation and transport of anthropogenic phosphorus in three river basins, Nat. Geosci., 9, 353356, 2016.

Read, D. S., Bowes, M. J., Newbold, L. K., and Whiteley, A. S.: Weekly flow cytometric analysis of riverine phytoplankton to determine seasonal bloom dynamics, Environ. Sci.-Proc. Imp., 16, 594-603, 2014.

Read, D. S., Gweon, H. S., Bowes, M. J., Newbold, L. K., Field, D., Bailey, M. J., and Griffiths, R. I.: Catchment-scale biogeography of riverine bacterioplankton, ISME J., 9, 516-526, 2015.

Singer, A. C., Järhult, J. D., Grabic, R., Khan, G. A., Lindberg, R. H., Fedorova, G., Fick, J., Bowes, M. J., Olsen, B., and Söderström, H.: Intra- and Inter-Pandemic Variations of Antiviral, Antibiotics and Decongestants in Wastewater Treatment Plants and Receiving Rivers, PLoS One, 9, e108621, https://doi.org/10.1371/journal.pone.0108621, 2014.

Skeffington, R. A., Halliday, S. J., Wade, A. J., Bowes, M. J., and Loewenthal, M.: Using high-frequency water quality data to assess sampling strategies for the EU Water Framework Directive, Hydrol. Earth Syst. Sci., 19, 2491-2504, https://doi.org/10.5194/hess-19-2491-2015, 2015.

Skougstad, M. W., Fishman, M. J., Friedman, L. C., Erdmann, D. E., and Duncan, S. S.: Methods for analysis of inorganic substances in water and fluvial sediments, U.S. Geological Survey, Report no. 78-679, 545 pp., 1978.

Smith, J. T., Clarke, R. T., and Bowes, M. J.: Are groundwater nitrate concentrations reaching a turning point in some chalk aquifers?, Sci. Total Environ., 408, 4722-4732, 2010.

Turner, G. S. C., Mills, G. A., Bowes, M. J., Burnett, J. L., Amos, S., and Fones, G. R.: Evaluation of DGT as a long- 
term water quality monitoring tool in natural waters; uranium as a case study, Environ. Sci.-Proc. Imp., 16, 393-403, https://doi.org/10.1039/C3EM00574G, 2014.

Wade, A. J., Palmer-Felgate, E. J., Halliday, S. J., Skeffington, R. A., Loewenthal, M., Jarvie, H. P., Bowes, M. J., Greenway, G. M., Haswell, S. J., Bell, I. M., Joly, E., Fallatah, A., Neal, C., Williams, R. J., Gozzard, E., and Newman, J. R.: Hydrochemical processes in lowland rivers: insights from in situ, highresolution monitoring, Hydrol. Earth Syst. Sci., 16, 4323-4342, https://doi.org/10.5194/hess-16-4323-2012, 2012.

Whitehead, P. G., Bussi, G., Bowes, M. J., Read, D. S., Hutchins, M. G., Elliott, J. A., and Dadson, S. J.: Dynamic modelling of multiple phytoplankton groups in rivers with an application to the Thames river system in the UK, Environ. Model. Softw., 74, 75-91, 2015.
Williams, R. J., White, C., Harrow, M. L., and Neal, C.: Temporal and small-scale spatial variations of dissolved oxygen in the Rivers Thames, Pang and Kennet, UK, Sci. Total Environ., 251, 497-510, 2000.

Wright, J. F., Gunn, R. J. M., Winder, J. M., Wiggers, R., Vowles, K., Clarke, R. T., and Harris, I.: A comparison of the macrophyte cover and macroinvertebrate fauna at three sites on the River Kennet in the mid 1970s and late 1990s, Sci. Total Environ., 282, 121-142, 2002. 